Received Date : 28-Jul-2015

Revised Date : 13-Jan-2016

Accepted Date : 15-Jan-2016

Article type : Regular Article

\title{
Energy cost and putative benefits of cellular mechanisms modulating buoyancy in aflagellate marine phytoplankton ${ }^{1}$
}

Michel Lavoie ${ }^{1}$

Québec-Océan and Unité Mixte Internationale Takuvik Ulaval-CNRS, Département de Biologie, Université Laval, Québec, Québec, Canada G1V 0A6.

John A Raven ${ }^{2}$

Division of Plant Science, University of Dundee at the James Hutton Institute, Invergowrie, Dundee DD2 5DA, UK (permanent address of JAR)

Functional Plant Biology and Climate Change Cluster (C3), University of Technology Sydney, Ultimo, NSW 2007, Australia

Maurice Levasseur

Québec-Océan and Unité Mixte Internationale Takuvik Ulaval-CNRS, Département de Biologie, Université Laval, Québec, Québec, Canada G1V 0A6.

This article has been accepted for publication and undergone full peer review but has not been through the copyediting, typesetting, pagination and proofreading process, which may lead to differences between this version and the Version of Record. Please cite this article as doi: 10.1111/jpy.12390-15-143

This article is protected by copyright. All rights reserved. 
${ }^{2}$ corresponding author

e-mail: j.a.raven@dundee.ac.uk

Editorial Responsibility: J. Raven (Associate Editor)

Running head: Bioenergetics of algal buoyancy

Keywords: Silica mineralization, nitrogen, glycine betaine, dimethylsulfoniopropionate, carbohydrates, coccoliths

List of Abbreviations: dimethylsulfoniopropionate (DMSP); trimethylammonium $\left(\mathrm{TMA}^{+}\right.$); trimethylglycine (TMG); transparent exopolymer particles (TEP); ammonium $\left(\mathrm{NH}_{4}^{+}\right)$; nitrate $\left(\mathrm{NO}_{3}{ }^{-}\right)$

\begin{abstract}
Little information is available on the energetics of buoyancy modulation in aflagellate phytoplankton, which comprise the majority of autotrophic cells found in the ocean. Here we computed for three aflagellate species of marine phytoplankton (Emiliania huxleyi, Thalassiosira
\end{abstract}

This article is protected by copyright. All rights reserved. 
pseudonana, and Ethmodiscus rex) the theoretical minimum energy cost as photons absorbed and nitrogen resource required of the key physiological mechanisms (i.e. replacement of quaternary ammonium by dimethylsulfoniopropionate, storage of polysaccharides, and cell wall biosynthesis) affecting the cell's vertical movement as a function of nitrogen $(\mathrm{N})$ availability. These energy costs were also normalized to the capacity of each buoyancy mechanism to modulate sinking or rising rates based on Stokes' law. The three physiological mechanisms could act as ballast in the three species tested in conditions of low $\mathrm{N}$ availability at a low fraction $(<11.9 \%)$ of the total photon energy cost for growth. Cell wall formation in E. huxleyi was the least costly ballast strategy whereas in $T$. pseudonana the photon energy cost of the three ballast strategies were similar. In E. rex, carbohydrate storage and mobilization appear to be energetically cheaper than modulations in organic solute synthesis to achieve vertical migration. This supports the carbohydrate ballast strategy for vertical migration for this species, but argues against the theory of replacement of low or high density organic solutes. The present study brings new insights into the energy cost and potential selective advantage of several strategies modulating the buoyancy of aflagellate marine phytoplankton.

\section{Introduction}

Light and nutrient availability for phytoplankton growth is generally vertically dissociated in the ocean. For this reason, phytoplankton cells developed different ways to move vertically, allowing them to use more efficiently the two limiting resources. Several dinoflagellates, prasinophytes, and raphidophytes as well as giant diatoms perform vertical migrations in order to benefit from the nutrient-rich deep reservoir at night and the well illuminated surface water

This article is protected by copyright. All rights reserved. 
during the day (Moore \& Villareal 1996a, Fauchot et al. 2005, Villareal et al. 2014, Shikata et al. 2015). While flagellates use a flagellar apparatus for propulsion, giant diatoms use a combination of ballast and positive buoyancy generation mechanisms such as active water transport (Raven $\&$ Doblin 2014), modulation in the intracellular concentration of "light" or "heavy" inorganic ions (Moore \& Villareal 1996a) or organic solutes (Boyd \& Gradmann 2002, Lavoie et al. 2015) as well as storage and consumption of polysaccharides (Moore \& Villareal 1996a). Note that throughout the manuscript, we use the term buoyancy to refer to sinking and rising, while positive, negative, and neutral buoyancy means rising, sinking and no net movement, respectively, relative to the immediately surrounding water.

Others adaptations that can modulate phytoplankton buoyancy include the presence of gas vesicles in cyanobacteria (Pfeifer 2012), changes in cell morphology, i.e., cell shape or size (Padisak et al. 2003), formation of colony or chain (Alldredge \& Cracker 1995) and an unknown swimming mechanism in the cyanobacterium Synechococcus (Palenik et al. 2003, Ehlers \& Oster 2012, Guasto et al. 2012). In addition, some flagellate prasinophyceans have nonmotile positively buoyant long-lasting cysts or phycoma life stages (Villareal et al. 2014).

For small non-gas vesiculate aflagellate phytoplankton such as small diatoms and coccolithophores, which are invariably denser than seawater (Waite et al. 1997, Raven \& Waite 2004), it has been shown that modulation of intracellular composition via several physiological mechanisms could also result in ecologically significant changes in negative buoyancy. For instance, the sinking rate of these cells often increase in the low nutrient-high irradiance surface waters, which increase the likelihood of reaching nutrient-rich patches in the euphotic zone of the ocean in low turbulence conditions (Paasche 2001, Raven \& Waite 2004). This indirect modulation of sinking rate can be achieved by several mechanisms including 1) the synthesis of

This article is protected by copyright. All rights reserved. 
carbohydrates after depletion of ambient $\mathrm{NO}_{3}{ }^{-}$in the surface ocean facilitating cell sinking toward deep nutrient-rich water, the "carbohydrate-ballast" hypothesis (Kromkamp \& Walsby 1990, Richardson \& Cullen 1995); 2) modulation in the accumulation of "lighter" $\left(\mathrm{NH}_{4}^{+}, \mathrm{Na}^{+}\right.$, $\left.\mathrm{Cl}^{-}\right)$or "heavier" $\left(\mathrm{NO}_{3}{ }^{-}, \mathrm{K}^{+}\right)$inorganic ions in the vacuoles of dinoflagellates and diatoms (Gross \& Zeuthen 1948, Anderson \& Sweeney 1978, Kahn \& Swift 1978); 4) modulation in the synthesis of organic solutes that yield solution of low or high density (Lavoie et al. 2015); and 5) variations in the degree of mineralization (Raven and Waite (2004) and the references cited therein).

Besides buoyancy modulation, the above changes in the cell biochemical composition can have several other roles. For instance, at low nutrient or high light, the compatible solute dimethylsulfoniopropionate (DMSP) and carbohydrate could dissipate excess cellular energy (Stefels 2000) and DMSP can be an antioxidant, presumably with a chemical change that prevents the molecule affected from acting as a compatible solute (Sunda et al. 2002, Darroch et al. 2015). Also, thicker cell walls in nutrient-limited algae may deter grazing (Van Donk et al. 1997, Van Donk et al. 2011). Therefore, the energy invested in controlling the biochemical composition of the cell and modulating buoyancy provides several benefits to aflagellate algal cells.

Even though aflagellate vegetative phytoplanktonic algae comprise the majority of phytoplankton cells found in the euphotic zone of the ocean, few reports have studied the energy cost and putative benefits of buoyancy modulation in these widely distributed organisms (Raven 1984b, Raven \& Doblin 2014). To gain insights into the potential selective advantages provided by different cellular strategies of buoyancy modulation in aflagellate phytoplankton, here we 
undertook an extensive theoretical analysis of the bioenergetics of vertical's cell movement in three aflagellate algal species.

We first chose two non-chain forming algal species: the widely distributed coccolithophore Emiliania huxleyi and the model diatom Thalassiosira pseudonana, which have been well characterized at the biochemical level. We then extended our analysis to the giant diatom Ethmodiscus rex, which is a good example of a diatom performing vertical migration in the oligotrophic open ocean and significantly contributing to nitrate transport to the euphotic zone (Villareal et al. 2014). We computed for these three phytoplankton species the theoretical minimum resource costs (as photons absorbed and nitrogen required) of key known physiological mechanisms [i.e., replacement of quaternary ammonium by DMSP, storage of polysaccharides, and cell wall biosynthesis] modulating cell's vertical movement in relation to the capacity of each buoyancy mechanism to modulate the sinking or rising rates calculated with the Stokes' law. First, we focused on the energy cost of an increase in cell sinking rate due to cell wall, polysaccharide and DMSP biosynthesis in conditions of $\mathrm{N}$ limitation in the two negatively buoyant species E. huxleyi and T. pseudonana. Second, we studied the energy cost associated with vertical migration of E. rex. Third, we evaluated how the modulation of cell's vertical movement afforded by changes in the biochemical composition of the cell compares on an energetic basis with the synthesis and operation of flagella and gas vesicles as well as with the running cost of active water transport. Putative benefits provided by several of the negative of positive buoyancy strategies examined in the present study are also discussed.

This article is protected by copyright. All rights reserved. 


\section{Modeling approach}

\section{Modeling the cell's vertical velocity}

The general modeling approach used to calculate the effect of cell wall, carbohydrate and DMSP synthesis on the sinking or rising rates achieved in the three chosen phytoplankton species has been previously explained in Lavoie et al. (2015). Our modeling procedure is summarized below and further details on the specific parameters and assumptions used for modeling the sinking rates of Thalassiosira pseudonana and Emiliania huxleyi and the rising rates of Ethmodiscus rex are described in supporting information (Appendix S1 sections 1.1, 1.2, and 1.3 in the Supporting Information).

Briefly, we computed the ballast afforded by cell wall biomineralization, carbohydrate (assumed to be mainly polysaccharide storage) and organic solute replacement by DMSP in the three chosen phytoplankton species growing in conditions of low N availability using the Stokes' law, which yields the cell's sinking $(v>0)$ or rising rate $(v<0)$ as a function of cell density and cell radius when the Reynolds number $<<1$.

$v=2 \mathrm{~g} \mathrm{r}_{\mathrm{eq}}^{2}\left(\rho_{\mathrm{c}}-\rho_{\mathrm{sw}}\right) / 9 \eta$ eq. 1

where $\mathrm{g}$ is the acceleration due to gravity $\left(9.81 \mathrm{~m}^{\cdot} \mathrm{s}^{-2}\right), \mathrm{r}_{\mathrm{eq}}$ the spherical equivalent cell radius (m), $\rho_{\mathrm{c}}$ the cell density $\left(\mathrm{kg} \cdot \mathrm{m}^{-3}\right), \rho_{\mathrm{sw}}$ the seawater density $\left(1024.9 \mathrm{~kg} \cdot \mathrm{m}^{-3}\right)$, and $\eta$ the dynamic viscosity of seawater at $20{ }^{\circ} \mathrm{C}\left(0.00108 \mathrm{~kg} \cdot \mathrm{m}^{-1} \cdot \mathrm{s}^{-1}\right)$. A $\rho_{\mathrm{sw}}$ of $1024.9 \mathrm{~kg} \cdot \mathrm{m}^{-3}$ was taken as representative of the mean composition of oceanic surface seawater as compiled by Sverdrup et al. $(1942)$ ( salinity $=34.32)$. $r_{\mathrm{eq}}$ was calculated from the experimentally measured mean cell volume (available in the literature, see Appendix S1 I section 1) assuming that all cells are single and spherical even for cylindrical diatoms since the Stokes' velocity is virtually insensitive to

This article is protected by copyright. All rights reserved. 
deviation of spherical cell shape in small cylindrical diatoms (Lavoie et al. 2015). The parameter $\rho_{\mathrm{c}}$ was computed from the cellular biochemical composition measured or modeled in N-limited (T. pseudonana and E. huxleyi) and N-depleted (E. rex) cells according to the modeling procedure described in Lavoie et al. (2015). The biochemical composition of each algal species that we used as input parameters in our model is shown in Tables 1 and 2. We then tested the sensitivity of each ballast strategy on the modeled cell's sinking (T. pseudonana and E. huxleyi) or rising (E. rex) rate assuming negligible turbulence.

For our model N-limited E. huxleyi species, the cell density was calculated using the biochemical data and cell radius reported by Paasche (1998) and Keller et al. (1999), based on N-limited chemostat cultures of E. huxleyi strains BOF-92 and CCMP 378, respectively. Since no data exist, to our knowledge, on the osmolarity of E. huxleyi, and that this species is thought to be hyperosomolar to seawater (Sikes \& Wilbur 1982), we assumed that our model E. huxleyi cell was $20 \%$ hyperosmolar to seawater and we estimated the intracellular concentration of all inorganic ions using various assumptions (Appendix S1 section 1.1). We adjusted the cell osmolarity with assumed concentrations of trimethylammonium $\left(\mathrm{TMA}^{+}\right.$) and $\mathrm{Cl}^{-}$and measured concentrations of trimethylglycine (TMG) and DMSP. Note that assuming a lower cell osmolarity ( $10 \%$ instead of $20 \%$ higher than seawater) affected by less than one percent the ballast effect afforded by calcification, carbohydrate or DMSP synthesis. This indicates that our assumption regarding the cell osmolarity should have little effect on our calculations. The sensitivity of the modeled cell's sinking rate to each ballast strategy was tested allowing the proportion of cell $\mathrm{C}$ allocated to carbohydrate and lipid to vary.

This article is protected by copyright. All rights reserved. 
For our model N-limited T. pseudonana cell, the cell density was determined with the protein, silica, organic C and cell radius measured by Claquin et al. (2002) in T. pseudonana CCMP 1015 growing in N-limited continuous cultures. We used a fixed cell osmolarity $18 \%$ higher than seawater osmolarity (Guillard 1962), estimated the intracellular concentrations of inorganic ions using some assumptions described in Appendix S1 section 1.2, and adjusted the cell osmolarity with assumed concentrations of $\mathrm{TMA}^{+} \mathrm{Cl}^{-}$and measured concentrations of DMSP and TMG. As for E. huxleyi, we considered different proportion of cell $\mathrm{C}$ allocated to carbohydrate and lipid.

For the giant diatom E. rex, the cell density was calculated using the morphological and biochemical data available in the literature for rising E. rex cells. Briefly, we used the cell size and Si cell quotas measured in E. rex by Villareal and Carpenter (1994) and we estimated the amount of structural components with the empirical relationships of Hitchcock (1982). The intracellular composition in inorganic ions was from Beklemishev et al. (1961), Guillard (1962) and Villareal and Lipshultz (1995) supplemented with $380 \mathrm{mmol}^{\cdot} \mathrm{L}^{-1}$ of the putative organic osmolyte $\mathrm{TMA}^{+}$and the counter-ion $\mathrm{Cl}^{-}$to adjust the cell osmolarity to that of seawater. In the above conditions (no DMSP, base level Si and carbohydrate) the cells were positively buoyant

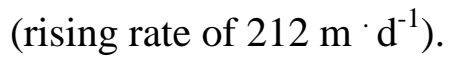

\section{Mechanistic energy cost computations}

The minimum energy cost (as ATP and NAD(P)H as well as N) of each mechanism modulating buoyancy was computed for the three species based on the biochemical pathways (Appendix S1 sections 2 to 10). For DMSP, $\mathrm{TMA}^{+}$and TMG related calculations, intracellular turnover or efflux from the cells were not considered. For DMSP, turnover rate and efflux are slow and

This article is protected by copyright. All rights reserved. 
should not affect appreciably our calculations (Laroche et al. 1999, Stefels et al. 2009), while no data on turnover and efflux of $\mathrm{TMA}^{+}$and $\mathrm{TMG}$ are available, to our knowledge, in the literature. The ATP and $\mathrm{NAD}(\mathrm{P}) \mathrm{H}$ energy costs were then converted on a basis of mol absorbed photons per cell as explained in Appendix S1 sections 2 to 10 and were also normalized relative to the ballast effect they afforded (mol absorbed photon per cell per unit ballast). This was done by dividing the absorbed photons cost per cell by the percentage of increase in sinking rate (for $E$. huxleyi and T. pseudonana) or of decrease in rising rate (for E. rex) and then by multiplying the

result by a constant $\left(10^{14}\right)$ so that the energy cost per ballast unit was on a scale between 1 to $10^{7}$. In each species, the photon energy cost of each buoyancy mechanism relative to the total photon energy cost per cell for the production of the total organic cell C was also computed. As an estimate of the total photon energy cost per cell, we used the photon cost of particulate organic C in algal biomass determined by Kliphuis et al. (2012), i.e., 24 mol absorbed photons per mol of particulate algal organic $\mathrm{C}$. This photon cost agrees with mechanistic calculations based on Raven et al. (2014) and Raven and Ralph (2015), with some allowance for lack of waste minimization in metabolism.

\section{Results and discussions}

\section{The ballast effect of coccoliths, carbohydrate and DMSP in N-limited Emiliania huxleyi}

We first considered the effect of calcification on the sinking rate of a model calcifying strain of E. huxleyi. The mass of calcite in coccoliths of the model N-limited E. huxleyi strain makes up a major fraction of total cell mass (i.e. from 64 to $73 \%$ of total cell mass) according to our calculations. Hence, a measured $65 \%$ increase in calcite mass per cell in N-limited E. huxleyi

This article is protected by copyright. All rights reserved. 
increases the modeled sinking rate by 49 to $69 \%$ when considering proportions of cell $\mathrm{C}$ in carbohydrate of 60 to $10 \%$, respectively, and proportions of cell C in lipid of 25 to $75 \%$, respectively (Fig. 1).

Second, the ballast effect of an over-production of carbohydrates under $\mathrm{N}$ limitation was quantitatively assessed in E. huxleyi. To do so, we simulated in our model N-limited E. huxleyi cell the ballast effect of a 1.54-fold increase in total cell carbohydrate at constant lipid cell quotas assuming that $25 \%$ of cell $\mathrm{C}$ is allocated to lipid. This increase in carbohydrate approximated the 1.54-fold increase in cell quotas of storage polysaccharides ( $\beta-1,3$ glucan) as measured by Pantorno et al. (2013) in N-limited E. huxleyi cells (strain CS-812), assuming that all carbohydrates are storage polysaccharides (i.e. neglecting carbohydrates in cocccoliths). The C from carbohydrate cell quotas in $\mathrm{N}$ replete cells was assumed to range between 10 to $40 \%$ of total cell $\mathrm{C}$ quotas. When carbohydrate cell quotas increases 1.54 -fold, the sinking rate increases by 2 to 7\% (Fig. 2A) depending on the initial carbohydrate cell quota. The sensitivity of sinking rate to a rise in cell carbohydrate increases as the proportion of cell mass allocated to carbohydrate increases, but differs by less than $3 \%$ when assuming a 2-fold increase or decrease in cell lipid quotas (data not shown).

Third, the potential ballast effect of (assumed) $\mathrm{TMA}^{+} \mathrm{Cl}^{-}$and (measured) TMG replacement by (measured) DMSP was evaluated in our model calcifying E. huxleyi cell. By contrast to the strong ballast effect of calcification, our calculations indicate that replacement of the putative $\mathrm{TMA}^{+}$ions, its counter-ions $\mathrm{Cl}^{-}$, and TMG, by the denser DMSP in conditions of $\mathrm{N}$ limitation caused a small decrease in the sinking rate of E. huxleyi, notably as a result of the low proportion of total cell mass ascribed to organic solutes. Even when assuming a relatively high intracellular osmolarity (20\% higher than seawater) and replacement by DMSP of one of the least dense

This article is protected by copyright. All rights reserved. 
organic cations and inorganic anions known, we show that a 52\% increase in intracellular DMSP (from 59 to $90 \mathrm{mmol} \cdot \mathrm{L}^{-1}$ ) and an associated decrease in the concentration of TMG (from 0.5 to 0 mmol $\mathrm{L}^{-1}$ ) as well as $\mathrm{TMA}^{+}$(from 391 to $370 \mathrm{mmol}^{\cdot} \mathrm{L}^{-1}$ ) and $\mathrm{Cl}^{-}$(from 528 to $507 \mathrm{mmol}^{\cdot} \mathrm{L}^{-1}$ ) only increased by 0.09 to $0.12 \%$ the sinking rate of our model calcifying E. huxleyi cells (Fig. 2A, and Table S1 in the Supporting Information). The low sensitivity of the sinking rate to organic solutes replacement in our model calcifying E. huxleyi cell is in line with the modeling results of Lavoie et al. (2015). The latter authors have shown that an increase in intracellular DMSP concentration from 40 to $420 \mathrm{mmol} \cdot \mathrm{L}^{-1}$ (approximating the range of concentrations measured in different E. huxleyi strains) and an associated decrease in $\mathrm{TMA}^{+} \mathrm{Cl}^{-}$in a calcifying strain of E. huxleyi CCMP 374 increased the modeled sinking rate by less than $1 \%$. Taken together, these results indicate that the preferential synthesis of carbohydrate in conditions of low $\mathrm{N}$-limited growth caused a smaller increase in the sinking rate of $E$. huxleyi than an increase in calcification, but a greater increase in the sinking rate than that resulting from the replacement of organic solutes by DMSP.

Our modeled sinking rates in E. huxleyi falls within the range of measured sinking rate of nutrient replete or nutrient-limited E. huxleyi (sinking rates of $\approx 0.01$ to $0.5 \mathrm{~m}^{\cdot} \mathrm{d}^{-1}$ for naked or plated E. huxleyi cells; Paasche 2001, Pantorno et al. 2013). While the sinking rate of E. huxleyi cells has been shown to increase in conditions of nitrogen or phosphorus limitation (Linschooten et al. 1991, Young \& Westbroek 1991, Lecourt et al. 1996, Paasche 2001), it is important to mention that the long range vertical transport of coccolithophores in the ocean is mediated primarily by their agglutination/aggregation with fecal pellets, clay particles and transparent exopolymer particles (TEP; Paasche 2001, Passow 2004). However, the few solitary E. huxleyi cells sinking at very low rates, which are modulated by nutrient limitation, could remain in the 
euphotic zone all year long while deep convective mixing during winter months could provide seed stock of E. huxleyi cells for the next summer's coccolithophore bloom in the ocean [as hypothesized by Fritz and Balch (1996)]. Although spring E. huxleyi blooms may also be seeded by overwintering flagellate haploid uncalcified heterococcolith phase of E. huxleyi, this possibility is unlikely since this flagellate haploid phase of E. huxleyi has not been reported so far in surface waters in winter (Frada et al. 2008, Frada et al. 2012)..

\section{The energy cost of different ballast strategies in N-limited Emiliania huxleyi}

The ballast mechanisms in E. huxleyi considered in the present study involve a low proportion of the total amount of absorbed photons required for growth (0.43 to 9.48\%) (Table 3; For further detail on these calculations see Appendix S1 sections 5, 7, and 8). Likewise, all three tested cellular strategies of sinking rate modulation appear to be affordable on the basis of the amount of $\mathrm{N}$ required (Table 3). Indeed, based on our present knowledge on the production of polysaccharides and coccoliths (Appendix S1 sections 7 and 8), both strategies involve the utilization of relatively few proteins and probably use a small proportion of total cell N. Moreover, DMSP biosynthesis redistributes $\mathrm{N}$ for the synthesis of new amino acids (Stefels 2000) and does not lead to a net consumption or production of N (Appendix SI section 4). Based on the amount of $\mathrm{N}$ incorporated in quaternary ammonium compounds ( $\mathrm{TMA}^{+}$and $\mathrm{TMG}$ ), we calculate that the replacement of $\mathrm{TMA}^{+}$and TMG by DMSP in E. huxleyi could decrease the total cell $\mathrm{N}$ requirement for growth by around 2\% (Table 3). Replacing organic solutes by DMSP is the only strategy resulting in a decrease in the $\mathrm{N}$ cell requirement. Using an extended Redfield ratio of 1844 photons: 106C: 16N (Raven 1984a) and converting the $\mathrm{N}$ resource cost in

This article is protected by copyright. All rights reserved. 
"extended" photon energy cost required for $\mathrm{N}$ synthesis, the photon energy saved by the replacement of $21.5 \mathrm{mM} \mathrm{TMA}^{+} / \mathrm{TMG}$ is slightly higher than the absorbed photon cost per cell for DMSP synthesis. This suggests that the saving on $\mathrm{N}$ resources due to $\mathrm{TMA}^{+} / \mathrm{TMG}$ replacement by DMSP could represent a substantial benefit to E. huxleyi.

Our calculations show that the photon energy cost per cell on a ballast unit basis is the lowest for calcification, intermediate for carbohydrate, and the highest for DMSP synthesis (Fig. 2B). The energy cost of organic solute replacement by DMSP will however depend on few other assumptions. On one hand, the small ballast effect of DMSP computed in the present study should be viewed as an upper limit since we assumed the replacement of an organic cation $\left(\mathrm{TMA}^{+}\right)$and an inorganic anion $\left(\mathrm{Cl}^{-}\right)$yielding solutions of low density. Therefore, we must underscore that our photon energy cost on a ballast unit basis of the "DMSP-ballast" strategy could be underestimated if DMSP replaces other organic solutes that are denser than $\mathrm{TMA}^{+} \mathrm{Cl}^{-}$. On the other hand, the cost of the "DMSP-ballast" strategy does not consider the potential uptake of dissolved DMSP, which is much less costly than de novo synthesis of DMSP in the cells: 93 mol absorbed photons per mol de novo synthesized DMSP vs 1 mol absorbed photon per mol DMSP transport from the external medium to the intracellular milieu (Appendix SI section 4). DMSP uptake by E. huxleyi has been demonstrated in laboratory (Spielmeyer et al. 2011). Whether or not DMSP uptake takes place, the "DMSP-ballast" strategy might be as energetically favorable (in terms of $\mathrm{N}$ saved and net photon cost) as the carbohydrate synthesis and coccolith formation strategies are assuming the synthesis of nitrogenous osmolytes although the relative increase in sinking rate afforded by DMSP is low compared to that achieved with other ballast mechanisms (Fig. 2A).

This article is protected by copyright. All rights reserved. 


\section{The ballast effect of silica, carbohydrate and DMSP in N-limited Thalassiosira pseudonana}

First, we examined the effect of silicification on the sinking rate of N-limited T. pseudonana. Our calculations show that a 4.5-fold measured increase in Si mineralization in T. pseudonana as the growth rate decreases from 0.6 to $0.2 \mathrm{~d}^{-1}$ increases the modeled sinking rate by $16,20,26,38$, and $68 \%$ when assuming that $60,50,40,30$, and $20 \%$, respectively, of cell C is incorporated in carbohydrate and $5,15,25,35$, and $45 \%$ of cell $\mathrm{C}$ is allocated to lipid (Fig. 3). Under $\mathrm{N}$ and $\mathrm{P}$ limitation, it has been shown that a higher proportion of cells in cultures of $T$. pseudonana remains in the G2 and M phases (G2: second growth period in the cell cycle and M: mitosis phase) for a longer period (Claquin et al. 2002). They are the two phases of the cell cycle where Si uptake, mineralization and valve formation, hence silicification, mainly occur (Sullivan 1976, Martin-Jezequel et al. 2000), thus explaining at least partly the observed increase in silicification in nutrient-limited cells of this species.

Second, carbohydrate storage as a ballast mechanism was investigated. Here we choose to compute the ballast effect of an assumed 1.54-fold increase in carbohydrate cell quotas, i.e. the same increase as the one assumed for E. huxleyi keeping in mind that $\mathrm{N}$ limitation has been shown to increase carbohydrate cell quotas by $10 \%$ to more than 2 -fold in several diatoms (Myklestad \& Haug 1972, Harrison et al. 1990, Granum et al. 2002). We fixed the proportion of cell C allocated to lipid to $23 \%$ (approximating the $23 \%$ of lipid mass relative to the total ashfree dry mass of T. pseudonana clone $3 \mathrm{H}$ measured by Harrison et al. (1990) in N-limited cells of T. pseudonana). We used a range of base level carbohydrate cell quotas in $\mathrm{N}$ replete cells of $15,20,30,40$ and $50 \%$ of total cell C (i.e., 46.3, 61.7, 95.5, 123.4 and 154.2 pg carbohydrate cell $^{-1}$ ) and evaluated the effect on the sinking rate of an assumed 1.54-fold increase in carbohydrate cell quotas in response to $\mathrm{N}$ limitation. Based on these assumptions, the ballast

This article is protected by copyright. All rights reserved. 
effect of carbohydrate would range from 31 to $45 \%$ (Fig. 2A) and would vary between 28 and $50 \%$ assuming a 2 -fold increase or decrease in lipid cell quotas (data not shown). Third, the potential ballast effect provided by the replacement of organic solutes (TMG and $\mathrm{TMA}^{+}$) by DMSP in T. pseudonana was assessed. When the measured DMSP concentration increases from 0.9 to $25 \mathrm{mmol} \mathrm{L}^{-1}$, the measured TMG concentration decreases from 2 to $0.2 \mathrm{mmol} \mathrm{L}^{-1}$, the assumed $\mathrm{TMA}^{+}$concentration decreases from 418.5 to $402.5 \mathrm{mmol} \cdot \mathrm{L}^{-1}$, and the assumed $\mathrm{Cl}^{-}$ concentration decreases from 522.9 to $506.9 \mathrm{mmol} \mathrm{L}^{-1}$, the cell sinking rate of $T$. pseudonana decreases by only 0.25 to $0.78 \%$ depending on the assumed carbohydrate and lipid cell quotas (Fig. 2A; Table S2 in the Supporting Information). This potential DMSP ballast effect in our model T. pseudonana strain was lower than the effect documented in another model study with the T. pseudonana strain CCMP 1335 for which the same increase in DMSP increased the sinking rate by 1 to $12 \%$ (Lavoie et al. 2015). This difference mostly results from the higher intracellular concentrations of dense structural components (silica, protein and carbohydrate) characterising strain CCMP 1335 (Lavoie et al. 2015) than strain CCMP 1015 (this study).

Our results show that the ballast effect of carbohydrate and cell wall in N-limited T. pseudonana was more important than the ballast afforded by DMSP production. Our modeled sinking rates

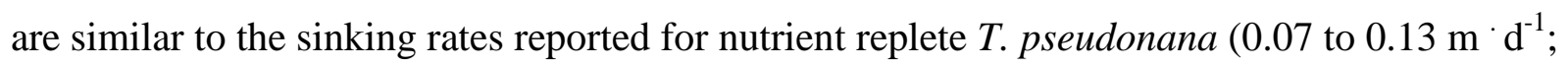
Bienfang \& Harrison 1984, Bach et al. 2012). It is important to note that other mechanisms not evaluated here can significantly modify the sinking rate of diatom cell. Nutrient limitation in diatoms has been shown to increase the production of cell chains and to stimulate TEP production (Thornton 2002, Bhaskar \& Bhosle 2005, Pedrotti et al. 2010), two processes that increase the effective size of diatoms, the sinking rate of aggregates/chains will further increase according to the Stokes' law (Miklasz \& Denny 2010). The relatively high sinking rate

This article is protected by copyright. All rights reserved. 
frequently observed in nutrient-limited diatoms may help exploit sporadic nutrient niches and is viewed as a part of the diatom life cycle, in which mostly coastal and neritic species as well as some open ocean species form resting cells or spores in deep and dark water. These spores can seed and potentially colonize more favourable oceanic areas via upwelling systems or seasonal mixing of the surface layer (Smetacek 1985, McQuoid \& Hobson 1996).

\section{The energy cost of different ballast strategies in N-limited $T$. pseudonana}

The three physiological mechanisms of sinking rate modulation investigated in N-limited $T$. pseudonana cells require a relatively small fraction $(0.12$ to $12 \%)$ of the total photon cost for growth (Table 3, Appendix S1 sections 5, 6, and 8). By contrast to the absorbed photon costs, the $\mathrm{N}$ requirement and related resource cost was very different for the three cell strategies with cell wall biomineralization being potentially much more costly than polysaccharide or DMSP synthesis (Table 3). The formation of siliceous cell walls involves the synthesis and addition of several amino acids within the cell wall (Hecky et al. 1973, Swift \& Wheeler 1992). Assuming that the relative proportion of organic components remains the same as the amount of $\mathrm{Si}$ increased in the cell wall of N-limited T. pseudonana cells, our calculations suggest that cell wall formation could be a costly process in terms of $\mathrm{N}$, i.e., $\mathrm{N}$ in cell wall accounting for 24 to $40 \%$ of the total $\mathrm{N}$ cell quotas. However, if the proportion of organic components decreased as the $\mathrm{Si}$ increased in the cell wall, then the proportion of total cellular $\mathrm{N}$ required for cell wall biosynthesis would be lower than the values presented above. Despite its potentially large N cost, the organic component of the diatom cell wall is important for the ballast role (and other roles) of

This article is protected by copyright. All rights reserved. 
the silica by decreasing the dissolution rate by two orders of magnitude in water bodies that are invariably undersaturated with respect to amorphous silica (Natori et al. 2006).

Contrary to cell wall formation, the preferential synthesis of the non-nitrogenous DMSP over Ncontaining organic solutes, whose concentrations are assumed to be around $100-400 \mathrm{mmol} \cdot \mathrm{L}^{-1}$ for osmotic purpose, would decrease the cell $\mathrm{N}$ requirement for growth by around $2 \%$ while affording a negligible ballast effect $(<0.78 \%)$. Converting the $\mathrm{N}$ resource cost in extended photon energy cost required for $\mathrm{N}$ synthesis as we did for E. huxleyi, we calculated that the replacement of around $15 \mathrm{mmol} \mathrm{L}^{-1}$ nitrogenous organic solutes by DMSP would save more absorbed photons than the absorbed photon cost of DMSP synthesis per cell. This suggests that the potential saving on $\mathrm{N}$ resources due to $\mathrm{TMA}^{+}$and TMG replacement by DMSP could represent a substantial benefit to T. pseudonana as suggested in E. huxleyi.

The photon energy cost normalized to the ballast effect is similar for all three ballast mechanisms in T. pseudonana (Fig. 2B). As discussed for E huxleyi, the energy cost of DMSP per unit ballast depends on the composition ( $\mathrm{N}$ content) and density of the solute to be replaced as well as to the extent of DMSP uptake from solution, which could take place in diatoms (Vila-Costa et al. 2006, Spielmeyer et al. 2011). Nevertheless, our results show that the photon energy cost per unit ballast of de novo DMSP synthesis as a ballast strategy in T. pseudonana could be comparable to that of cell wall and polysaccharide ballast strategies assuming that DMSP replaces low-density organic solutes (such as $\mathrm{TMA}^{+} \mathrm{Cl}^{-}$). The energy cost of the DMSP ballast strategy could be lower than the two other ballast strategies considering the amount of $\mathrm{N}$ saved due to the replacement by DMSP or assuming that DMSP is taken up from the medium rather than de novo synthesized, although the concentration of dissolved DMSP in seawater is very low (usually less than $2.8 \mathrm{nmol} \mathrm{L}^{-1}$; Kiene \& Slezak 2006). By contrast, siliceous cell wall production could be a

This article is protected by copyright. All rights reserved. 
costly ballast strategy in T. pseudonana in terms of $\mathrm{N}$ (Table 3) even though the photon energy cost per ballast unit for the cell wall and the polysaccharide ballast strategies was comparable (Fig. 2B).

\section{The ballast effect of silica, carbohydrate and DMSP in the diatom Ethmodiscus rex}

The third species we studied is the giant-celled diatom E. rex, a species known to undergo vertical migrations in oligotrophic parts of the ocean (Villareal \& Carpenter 1994). In N replete conditions, this diatom can potentially rise at rates of 10 to $119 \mathrm{~m} \mathrm{day}^{-1}$ (Moore \& Villareal 1996b). Such high rising rates are of the same order of magnitude as the swimming speeds of motile dinoflagellates (Crawford 1992). As E. rex rises and become gradually $\mathrm{N}$ depleted, different ballast mechanisms must act to progressively decrease its rising rate.

Our computations show that increases in the silica cell quotas by 2,4 , and 10 times decrease cell rising rates by $0.5\left(212\right.$ to $\left.211 \mathrm{~m}^{\cdot} \mathrm{d}^{-1}\right), 2\left(212\right.$ to $\left.211 \mathrm{~m}^{\prime} \mathrm{d}^{-1}\right)$, and $7 \%\left(212\right.$ to $\left.198 \mathrm{~m}^{\cdot} \mathrm{d}^{-1}\right)$, respectively. Similarly, increases in carbohydrate cell quotas by 1.25-, 1.5-, and 2-fold decrease the rising rate of E. rex by 3,6, and 13\%, respectively. By comparison, the replacement of 10 mmol ${ }^{-1} \mathrm{~L}^{-1}$ assumed $\mathrm{TMA}^{+} \mathrm{Cl}^{-}$by $14 \mathrm{mmol} \cdot \mathrm{L}^{-1}$ assumed DMSP decreases the cell rising rate by about 3\%. Our results summarized in Figure 2A are in line with those of Woods and Villareal (2008) who showed that the cell density of E. rex is weakly sensitive to large change (10-fold variation) in silica mineralization due to its low surface:volume quotient. In summary, our calculations show that an increase in polysaccharide storage decreases the rising rate of $E$. rex more than a similar relative increase in cell wall biomineralization, whereas the synthesis of an assumed $14 \mathrm{mmol}{ }^{-1}$ of DMSP replacing the assumed osmolyte $\mathrm{TMA}^{+} \mathrm{Cl}^{-}$decreases the rising 
rate of E. rex as efficiently as a 1.25- and 4- fold increase in carbohydrate and silica quotas, respectively.

\section{The energy cost of different ballast strategies in the diatom Ethmodiscus rex}

The three ballast strategies tested in the previous section consume a low fraction (1.1 to $4.3 \%)$ of the total amount of absorbed photons per cell required for the synthesis of the total particulate organic carbon per E. rex cell (Table 3, see detailed on the calculation of energetic costs in the Appendix S1 sections 5, 6, and 8). The synthesis of $14 \mathrm{mmol}^{\cdot} \mathrm{L}^{-1}$ (assumed) DMSP require 2.4 to $3.5 \%$ of the total cell energy expressed as absorbed photons suggesting that the synthesis of $100 \mathrm{mmol} \mathrm{L}^{-1} \mathrm{DMSP}$ or more could represent a non-negligible energy expenditure in E. rex. The replacement of $\mathrm{mmol} \cdot \mathrm{L}^{-1} \mathrm{TMA}^{+} \mathrm{Cl}^{-}$by de novo synthesized $14 \mathrm{mmol} \cdot \mathrm{L}^{-1} \mathrm{DMSP}$ could decrease the total cell $\mathrm{N}$ requirement by as much as $22 \%$. Using an extended photon cost as done above for T. pseudonana and E. huxleyi, we again calculate that the net photon cost of nitrogenous organic solute replacement by $14 \mathrm{mmol} \cdot \mathrm{L}^{-1} \mathrm{DMSP}$ should be much lower than the computed photon energy cost for the DMSP ballast strategy alone and could thus represent an affordable ballast strategy in N-depleted E. rex.

The $\mathrm{N}$ cost of a siliceous cell wall could be particularly high in E. rex. Indeed, using a proteins: $\mathrm{N}$ mass ratio of 6.25 (Geider \& Laroche 2002) and assuming that the relative proportion of proteins in the cell wall by weight is as high as that measured in Cyclotella meneghiniana by Swift and Wheeler (1992) (i.e., 30-51\% proteins by weight assuming no contaminations of the cell wall by intracellular organic $\mathrm{N}$ from the diatom), the amount of cellular $\mathrm{N}$ allocated to the cell wall of $\mathrm{N}$ replete E. rex cells (at base level Si cell quotas) would represent $28-44 \%$ of the total measured

This article is protected by copyright. All rights reserved. 
cell $\mathrm{N}$ quotas for $E$. rex cells. However, for N-depleted E. rex cells, the amount of cellular N allocated to the cell wall would exceed the mean total $\mathrm{N}$ cell quotas of $7 \mathrm{nmol} \mathrm{N}$ per cell measured in situ (Villareal \& Carpenter 1994). This suggests that the cost in N resource for cell wall formation could be relatively important, assuming that the $\mathrm{N}$-limited cells would maintain the high cell wall protein content measured by Swift and Wheeler (1992). Given the low sensitivity of the sinking rate to Si mineralization, the known presence of amino acids in siliceous cell wall (Appendix SI section 6), and the potential high $\mathrm{N}$ cost of cell wall biomineralization, our results suggest that an increase in Si mineralization could be a sub-optimal ballast strategy in E. rex.

The photon energy cost per unit ballast for the assumed carbohydrate synthesis and the putative organic solute replacement by de novo synthesized DMSP was similar (Fig. 2B). However, it is important to point out that this conclusion does not take into account the possible decrease in the energy cost of these two ballast mechanisms if carbohydrate respiration increases as the cell sinks and if E. rex takes up DMSP from the medium. Indeed, the potential cost of DMSP uptake is only $1 \mathrm{~mol}$ absorbed photons per mol DMSP transported from the external medium into the cell (Appendix S1 section 4). By comparison, the cost of polysaccharide storage is also only 1 mol absorbed photons per mol glucosyl unit added if we subtract the cost of synthesizing carbohydrate (Appendix S1 section 8; see next section for a discussion on the role of carbohydrate consumption on cell buoyancy). We thus conclude that the potential replacement of nitrogenous osmolytes by $14 \mathrm{mmol} \cdot \mathrm{L}^{-1}$ DMSP (either de novo synthesized or taken up from solution) for ballasting purpose could be as affordable as polysaccharide storage.

This article is protected by copyright. All rights reserved. 


\section{The energy cost of buoyancy strategies involved in vertical migration of Ethmodiscus rex}

We could not compute the energy cost associated with modulation of intracellular ion concentrations as a strategy of buoyancy regulation since knowledge of the mechanisms involved are insufficient (See Appendix S1 section 2 for further details). Regarding the synthesis of organic solutes, assuming that in order to achieve positive buoyancy, E. rex synthesizes in its vacuole $15.2 \mathrm{nmol}$ per cell or $100 \mathrm{mmol}^{\cdot} \mathrm{L}^{-1} \mathrm{TMA}^{+}$, the minimum photon cost would be 1.23 to $1.49 \mu \mathrm{mol}$ absorbed photon per cell (using the minimum photon cost for the biosynthesis of a mole of TMA ${ }^{+}$i.e., 81 and $98.25 \mathrm{~mol}$ absorbed photons with $\mathrm{NH}_{4}{ }^{+}$and $\mathrm{NO}_{3}{ }^{-}$, respectively, as the $\mathrm{N}$ source; Appendix S1 section 3). This photon cost represents a major fraction (51 to 62\%) of the total absorbed photon cost for the synthesis of the particulate total organic $\mathrm{C}$ in a $E$. rex cell (2.39 $\mu \mathrm{mol}$ absorbed photon per cell). By comparison, the photon energy cost of active water transport could be around one order of magnitude lower than that for the synthesis of $\mathrm{mmol} \cdot \mathrm{L}^{-1}$ $\mathrm{TMA}^{+}$(Raven \& Doblin 2014).

The net photon energy cost of the polysaccharide storage and utilization strategy (i.e., the energy cost of polysaccharide storage minus the energy gained from the consumption of stored carbohydrate at depth) for negative/positive buoyancy generation by E. rex could be as low as for active water transport. We calculated that an excess in carbohydrate cell quotas relative to the base level carbohydrate quota by around 9-fold, estimated with the empirical relationships of Hitchcock (1982), could make fast rising E. rex cells non-buoyant. The synthesis and storage of these excess intracellular polysaccharides could represent $70 \%$ of the total photon energy cost for the synthesis of a whole E. rex cell, using an energy cost of 55 mol absorbed photons per mol of hexose in polysaccharides (Appendix S1 section 8). However, the stored polysaccharides produced at the surface will be gradually used by descending E. rex cells when encountering N-

This article is protected by copyright. All rights reserved. 
rich patches or, at greater depth, reaching the nitracline. In addition, in conditions of light limitation, the intracellular concentration of ballast polysaccharide could decrease due to growth dilution as the cell increase in size during their journey toward the nitracline. Taking a lower limit of the photon energy cost of 2 mol absorbed photon per cell for polysaccharide synthesis from sugar phosphate and mobilization (i.e., $1 \mathrm{~mol}$ for polysaccharide synthesis and $1 \mathrm{~mol}$ for carbohydrate mobilisation from polysaccharides) and assuming that the ballast effect of carbohydrate persists for several days and that all stored carbohydrates are eventually consumed (i.e. no loss occurring due to growth dilution), yields a lower limit of the net photon energy cost of the carbohydrate positive/negative buoyancy strategy of around $2.5 \%$ [70\% / (55/2)] of the total photon energy cost of synthesis of a whole E. rex cells. We thus conclude that polysaccharide storage during the day near the surface and their utilization at depth at night could explain the vertical migration of this species at a low fraction of the total cellular energy cost.

\section{The energy costs of gas vesicles and flagella, two mechanisms allowing upward or downward movement}

The energy cost of synthesis of the buoyancy-generating gas vesicle in cyanobacteria as a fraction of the energy cost required for whole cell synthesis is comparable to the minimum net relative energy cost computed above for synthesis and mobilization of storage polysaccharide in E. rex. Based on the composition of gas vesicle (Walsby 1994) and some assumptions about the organic $\mathrm{C}$ content and energy cost of particulate organic $\mathrm{C}$ synthesis (Appendix $\mathrm{S} 1$ section 10), we estimate that around 5 to $7 \%$ of the absorbed photon requirement for synthesis of a $0.6 \mu \mathrm{m}-$

This article is protected by copyright. All rights reserved. 
radius cyanobacterium is required for gas vesicle synthesis. We also calculated that $5 \%$ of total cell $\mathrm{N}$ is required for the synthesis of gas vesicles. According to Walsby (1994), gas vesicle production in cyanobacteria is less costly than the synthesis and use of bacterial flagella for generation times longer than around $11 \mathrm{~h}$; at higher growth rate, the reverse is true.

How these synthesis and operating costs calculated for bacteria compare with those associated with the flagellar apparatus of eukaryotic cells? We calculated that the cost of synthesis and operation of dinophyte flagella with the total photon energy required for growth is the lowest of all strategies of buoyancy generation or, in this case, its equivalent in upward swimming. Based on the known composition and operating mechanisms of eukaryotic flagella, we show that the photon energy cost of synthesis and operation of flagella is 3 to 4 orders of magnitude lower than the total photon cost for growth of a model dinophyte cell of $25 \mu \mathrm{m}$ equivalent spherical diameter (Appendix S1 section 10). Dinoflagellates performing diel migrations should, on the basis of energy costs, preferentially use flagella swimming instead of other indirect means of locomotion related to changes in biochemical composition. According to mechanistically-based calculations on the effect of DMSP and carbohydrate production on the downward swimming speed of motile migratory dinoflagellates, we indeed found that variations in DMSP and carbohydrate content of the dinoflagellates likely play a minor role (if any) in diel migrations of dinoflagellates (Appendix S1 section 11).

While dinoflagellates use flagella at a low fraction of the energy cost for growth, the very large, highly vacuolated cells of Ethmodiscus as well as Pyrocystis and the phycoma stage of Halosphaera, would only have 1-4 flagella per cell granted their ancestry. Even with unfeasibly long flagella, these flagella would be inadequate for propulsion of cells of $0.5-1 \mathrm{~mm}$ diameter comparing the maximum energy transduction by unit length of flagella and work against drag

This article is protected by copyright. All rights reserved. 
that is necessary for flagella motility (Raven \& Richardson 1984, Crawford 1992). Irrespective of the scaling effects of cell size on the energy cost of flagella in single cells, the benefits of collective use of flagella in large colonial freshwater phytoplanktonic species has been shown to outweigh their associated cost. Indeed, negatively buoyant phytoplankton colonies of Volvox cells in freshwater systems have evolved five times within the chlorophycean order Volvocales to produce a "pseudo-ciliate" with a non-living centre and up to $2^{15}$ cells per colony (Kirk 2003), and two flagella per cell.

At the other end of the size scale are the flagellate picophytoplankton (equivalent spherical diameter $<2 \mu \mathrm{m}$ ) such as the uniflagellate prasinophycean Micromonas pusilla (Raven 1998). Since the minimum length of a functional flagellum is $5 \mu \mathrm{m}$ (Sleigh \& Blake 1977) and flagellar diameter is invariably $0.2 \mu \mathrm{m}$ (Raven \& Richardson 1984), flagella volume is around $0.46 \%$ of the total volume of a $2-\mu \mathrm{m}$ radius cell, i.e., $\approx 40$ times that of the model dinoflagellate (Raven $\&$ Richardson 1984). Therefore, the capital (as photons and N) and running cost of flagella relative to the cost of total cell synthesis increases as cell size decreases. Furthermore, the force required per unit cell volume to overcome drag is expected to increase as the cell radius decreases, other things being equal (Solari et al. 2006). Despite these constraints, M. pusilla can swim at up to $100 \mu \mathrm{m}$ per second and so could potentially undergo up to $4.8 \mathrm{~m}$ diel vertical migration, although whether this is achieved is equivocal (Hilmer \& Bate 1991). .

This article is protected by copyright. All rights reserved. 


\section{Conclusions}

The present study shows that for small coccolithophores and diatoms an increase in cell wall, carbohydrate and DMSP synthesis could provide significant ballasts at a relatively low photon energy cost per cell. These ballast strategies are however more energy consuming than the synthesis and use of flagella in dinophytes. Although the ballast effect of DMSP is relatively small compared to that afforded by cell wall and polysaccharides, our results suggest that the energy (as photons and N) cost per unit ballast of de novo DMSP synthesis in T. pseudonana could be equal or lower than the energy cost associated to cell wall and polysaccharide ballast strategies assuming that DMSP replaces low density nitrogenous osmolytes. For the giant diatom E. rex, carbohydrate storage and mobilization appears to be energetically cheaper than potential modulation in cell wall or organic solute synthesis to achieve vertical migration. The carbohydrate strategy seems thus to be the most favorable one in this species.

In the ocean, the vertical distribution of aflagellate phytoplankton is a function of several parameters either intrinsic (e.g., cell chain formation, TEP production, modulation of the cell biochemical composition) or extrinsic to the algae (e.g., turbulence, aggregation to fecal pellets). Since this study focused on a selection of intrinsic parameters only, our results cannot predict the behavior and vertical distribution of these species in their natural environment. However, it brings new useful quantitative information on buoyancy modulation related to biochemical composition in aflagellate algae. More knowledge on the physiological interactions modulating phytoplankton buoyancy could help better parametrize models of marine phytoplankton dynamics and could also potentially improve prediction of carbon export in the ocean.

This article is protected by copyright. All rights reserved. 


\section{Acknowledgments}

Earlier versions of this manuscript have been greatly improved thanks to the insightful comments of two anonymous reviewers. This work was supported by postdoctoral fellowships from the Fonds de recherche du Québec - Nature et technologies and the Natural Sciences and Engineering Research Council of Canada (M Lavoie) as well as by the Canada Research Chair in Ocean Biogeochemistry and Climate (M Levasseur). The University of Dundee is a registered Scottish charity No SC015096.

\section{Supplementary Material}

The following supplementary material is available for this article:

Appendix S1. Section 1: Methodology for the modeling of the sinking and rising rates of different phytoplankton species. Section 2: TMG biosynthesis: biochemical pathway and energetics. Section 3: $\mathrm{TMA}^{+}$biosynthesis: biochemical pathway and energetics. Section 4: DMSP biosynthesis: biochemical pathway and energetics. Section 5: Energy cost and ballast effect of organic solutes $\left(\mathrm{TMA}^{+}\right.$and TMG) replacement by DMSP in two diatoms and a coccolithophore. Section 6: Cell wall formation in diatoms: biochemical mechanisms and energetics. Section 7: Coccolith formation: biochemical mechanism and energy cost. Section 8: Energy cost of storage polysaccharide synthesis. Section 9: Gas vesicles: ultrastructure, ecology and resource cost for their formation. Section 10: Energy cost of flagella use and maintenance. Section 11: Synthesis of the denser organic solute DMSP and diel migration in motile dinoflagellates. Section 12: Energy cost of manipulating the vacuolar ionic composition. 
Table S1. The effect of $\mathrm{TMA}^{+} \mathrm{Cl}^{-}$and TMG replacement by DMSP on the modeled sinking rate of a calcifying E. huxleyi strain grown under $\mathrm{N}$ limitation as a function of different proportion of cell $\mathrm{C}$ incorporated in carbohydrate and lipid.

Table S2. The effect of $\mathrm{TMA}^{+} \mathrm{Cl}^{-}$and TMG replacement by DMSP on the modeled sinking rate of T. pseudonana grown under $\mathrm{N}$ limitation as a function of different proportion of cell $\mathrm{C}$ incorporated in carbohydrate and lipid.

\section{References}

Alldredge, A. L. \& Cracker, K. M. 1995. Why do sinking mucilage aggregates accumulate in the water column? Sci. Total Environ. 165:15-22.

Anderson, L. W. J. \& Sweeney, B. M. 1978. Role of ionorganic ions in controlling sedimentation rate of a marine centric diatom Ditylum brightwellii. J. Phycol. 14:204-14.

Bach, L. T., Riebesell, U., Sett, S., Febiri, S., Rzepka, P. \& Schulz, K. G. 2012. An approach for particle sinking velocity measurements in the 3-400 mu $\mathrm{m}$ size range and considerations on the effect of temperature on sinking rates. Mar. Biol. 159:1853-64.

Beklemishev, K. B., Petrikova, M. N. \& Samina, G. I. 1961. On the cause of buoyancy of plankton diatoms. T. Inst. Okeanol. Akad. Nauk. SSSR 51:33-36.

Bhaskar, P. V. \& Bhosle, N. B. 2005. Microbial extracellular polymeric substances in marine biogeochemical processes. Curr. Sci. 88:45-53.

Bienfang, P. K. \& Harrison, P. J. 1984. Sinking rate response of natural assemblages of temperate and sub-tropical phytoplankton to nutrient depletion. Mar. Biol. 83:293-300.

Boyd, C. M. \& Gradmann, A. E. D. 2002. Impact of osmolytes on buoyancy of marine phytoplankton. Mar. Biol. 141:605-18.

Claquin, P., Martin-Jezequel, V., Kromkamp, J. C., Veldhuis, M. J. W. \& Kraay, G. W. 2002. Uncoupling of silicon compared with carbon and nitrogen metabolisms and the role of the cell cycle in continuous cultures of Thalassiosira pseudonana (Bacillariophyceae) under light, nitrogen, and phosphorus control. J. Phycol. 38:922-30.

Crawford, D. W. 1992. Metabolic cost of motility in planktonic protists: theoretical considerations on size scaling and swimming speed. Microb. Ecol. 24:1-10.

Darroch, L. J., Lavoie, M., Levasseur, M., Laurion, I., Sunda, W. G., Michaud, S., Scarratt, M. G., Gosselin, M. \& Caron, G. 2015. Effect of short-term light- and UV-stress on DMSP, DMS and DMSP lyase activity in Emiliania huxleyi. Aquat. Microb. Ecol. 74. DOI: 10.3354/ame01735:173-85.

Ehlers, K. \& Oster, G. 2012. On the Mysterious propulsion of Synechococcus. Plos One 7.

This article is protected by copyright. All rights reserved. 
Fauchot, J., Levasseur, M. \& Roy, S. 2005. Daytime and nighttime vertical migrations of Alexandrium tamarense in the St. Lawrence estuary (Canada). Mar. Ecol. Prog. Ser. 296:241-50.

Frada, M., Probert, I., Allen, M. J., Wilson, W. H. \& de Vargas, C. 2008. The "Cheshire Cat" escape strategy of the coccolithophore Emiliania huxleyi in response to viral infection. Proc. Natl. Acad. Sci. USA 105:15944-49.

Frada, M. J., Bidle, K. H., Probert, I. \& de Vargas, C. 2012. In situ survey of life cycle phase of coccolithophore Emiliania huxleyi (Haptophyta). Environ. Microbiol. 14:1558-69.

Fritz, J. J. \& Balch, W. M. 1996. A light-limited continuous culture study of Emiliania huxleyi: Determination of coccolith detachment and its relevance to cell sinking. J. Exp. Mar. Biol. Ecol. 207:127-47.

Geider, R. J. \& Laroche, J. 2002. Redfield revisited: variability of C:N:P in marine microalgae and its biochemical basis. Eur. J. Phycol. 37:1-17.

Granum, E., Kirkvold, S. \& Myklestad, S. M. 2002. Cellular and extracellular production of carbohydrates and amino acids by the marine diatom Skeletonema costatum: diel variations and effects of N depletion. Mar. Ecol. Prog. Ser. 242:83-94.

Gross, F. \& Zeuthen, E. 1948. The buoyancy of plankton diatoms: A problem of cell physiology. Proc. R. Soc. London, Ser. B 135:382-89.

Guasto, J. S., Rusconi, R. \& Stocker, R. 2012. Fluid Mechanics of Planktonic Microorganisms. Annu.. Rev. Fluid Mech. 44:373-400.

Guillard, R. R. L. 1962. Salt and osmotic balance. In Lewin, R. [Ed.] Physiology and biochemistry of algae. Academic Press, New York, pp. 529-40.

Harrison, P. J., Thompson, P. A. \& Calderwood, G. S. 1990. Effects of nutrient and light limitation on the biochemical composition of phytoplankton. J. Appl. Phycol. 2:45-56.

Hecky, R. E., Mopper, K., Kilham, P. \& Degens, E. T. 1973. The amino acid and sugar composition of diatom cell walls. Mar. Biol. 19:323-31.

Hilmer, T. \& Bate, G. C. 1991. Vertical migration of a flagellate-dominated bloom in a shallow South Arican Estuary. Bot. Mar. 34:113-21.

Hitchcock, G. L. 1982. A comparative study of the size-dependant organic composition of marine diatoms and dinoflagellates. J. Plankton Res. 4:363-77.

Kahn, N. \& Swift, E. 1978. Positive buoyancy through ionic control in non-motile marine dinoflagellate Pyrocystis noctiluca Murray ex Schuett. Limnol. Oceanogr. 23:649-58.

Keller, M. D., Kiene, R. P., Matrai, P. A. \& Bellows, W. K. 1999. Production of glycine betaine and dimethylsulfoniopropionate in marine phytoplankton. II. N-limited chemostat cultures. Mar. Biol. 135:249-57.

Kiene, R. P. \& Slezak, D. 2006. Low dissolved DMSP concentrations in seawater revealed by small-volume gravity filtration and dialysis sampling. Limnol. Oceanogr. Methods 4:8095.

Kirk, D. L. 2003. Seeking the Ultimate and Proximate Causes of Volvox Multicellularity and Cellular Differentiation. Integr. Comp. Biol. 43:247-53.

Kliphuis, A. M. J., de Winter, L., Vejrazka, C., Klok, A. J., Martens, D. E., Lamers, P. P., Janssen, M. \& Wijffels, R. H. 2012. Metabolic modelling of Chlamydomonas reinhardtii: energy requirements for photoautotrophic growth and maintenance. J. Appl. Phycol. 24:253-66.

Kromkamp, J. C. \& Walsby, A. E. 1990. A computer model of buoyancy and vertical migration in cyanobacteria. J. Plankton Res. 12:161-83.

This article is protected by copyright. All rights reserved. 
Laroche, D., Vézina, A., Levasseur, M., Gosselin, M., Stefels, J., Keller, M. D., Matrai, P. A. \& Kwint, R. L. J. 1999. DMSP synthesis and exudation in phytoplankton: a modeling approach. Mar. Ecol. Prog. Ser. 180:37-49.

Lavoie, M., Levasseur, M. \& Babin, M. 2015. Testing the potential ballast role for dimethylsulfoniopropionate in marine phytoplankton: A modeling study. J. Plankton Res. 0:1-13.

Lecourt, M., Muggli, D. L. \& Harrison, P. J. 1996. Comparison of growth and sinking rates of non-coccolith- and coccolith-forming strains of Emiliania huxleyi (Prymnesiophyceae) grown under different irradiances and nitrogen sources. J. Phycol. 32:17-21.

Linschooten, C., Vanbleijswijk, J. D. L., Vanemburg, P. R., Devrind, J. P. M., Kempers, E. S., Westbroek, P. \& Devrinddejong, E. W. 1991. Role of the light-dark cycle and medium composition on the production of coccoliths by Emiliania huxleyi (Haptophyceae). $J$. Phycol. 27:82-86.

Martin-Jezequel, V., Hildebrand, M. \& Brzezinski, M. A. 2000. Silicon metabolism in diatoms: Implications for growth. J. Phycol. 36:821-40.

McQuoid, M. R. \& Hobson, L. A. 1996. Diatom resting stages. J. Phycol. 32:889-902.

Miklasz, K. A. \& Denny, M. W. 2010. Diatom sinking speeds: Improved predictions and insight from a modified Stokes' law. Limnol. Oceanogr. 55:2513-25.

Moore, J. K. \& Villareal, T. A. 1996a. Buoyancy and growth characteristics of three positively buoyant marine diatoms. Mar. Ecol. Prog. Ser. 132:203-13.

Moore, J. K. \& Villareal, T. A. 1996b. Size-ascent rate relationships in positively buoyant marine diatoms. Limnol. Oceanogr. 41:1514-20.

Myklestad, S. \& Haug, A. 1972. Production of carbohydrates by the marine diatom Chaetoceros affinis Var. Willei Gran (Husdet) I. Effect of the concentration of nutrients in the culture medium. J. Exp. Mar. Biol. Ecol. 9:125-36.

Natori, Y., Haneda, A. \& Suzuki, Y. 2006. Vertical and seasonal differences in biogenic silica dissolution in natural seawater in Suruga Bay, Japan: Effects of temperature and organic matter. Mar. Chem. 102:230-41.

Paasche, E. 1998. Roles of nitrogen and phosphorus in coccolith formation in Emiliania huxleyi (Prymnesiophyceae). Eur. J. Phycol. 33:33-42.

Paasche, E. 2001. A review of the coccolithophorid Emiliania huxleyi (Prymnesiophyceae), with particular reference to growth, coccolith formation, and calcification-photosynthesis interactions. Phycologia 40:503-29.

Padisak, J., Soroczki-Pinter, E. \& Rezner, Z. 2003. Sinking properties of some phytoplankton shapes and the relation of form resistance to morphological diversity of plankton - an experimental study. Hydrobiologia 500:243-57.

Palenik, B., Brahamsha, B., Larimer, F. W., Land, M., Hauser, L., Chain, P., Lamerdin, J., Regala, W., Allen, E. E., McCarren, J., Paulsen, I., Dufresne, A., Partensky, F., Webb, E. A. \& Waterbury, J. 2003. The genome of a motile marine Synechococcus. Nature 424:1037-42.

Pantorno, A., Holland, D. P., Stojkovic, S. \& Beardall, J. 2013. Impacts of nitrogen limitation on the sinking rate of the coccolithophorid Emiliania huxleyi (Prymnesiophyceae). Phycologia 52:288-94.

Passow, U. 2004. Switching perspectives: Do mineral fluxes determine particulate organic carbon fluxes or vice versa? Geochem. Geophys. Geosy. 5:Q04002.

This article is protected by copyright. All rights reserved. 
Pedrotti, M. L., Peters, F., Beauvais, S., Vidal, M., Egge, J., Jacobsen, A. \& Marrase, C. 2010. Effects of nutrients and turbulence on the production of transparent exopolymer particles: a mesocosm study. Mar. Ecol. Prog. Ser. 419:57-69.

Pfeifer, F. 2012. Distribution, formation and regulation of gas vesicles. Nat. Rev. Microbiol. 10:705-15.

Raven, J. A. 1984a. Energetics and Transport in Aquatic Plants. A. R. Liss, New York,

Raven, J. A. 1984b. Vacuoles: storage, flotation, and amplification of surface/volume ratio of cytoplasm. Energetics and transport in aquatic plants. Liss, New York, pp. 411-70.

Raven, J. A. 1998. The twelfth Tansley Lecture. Small is beautiful: the picophytoplankton. Funct. Ecol. 12:503-13.

Raven, J. A., Beardall, J. \& Giordano, M. 2014. Energy costs of carbon dioxide concentrating mechanisms in aquatic organisms. Photosynthesis Res. 121:111-24.

Raven, J. A. \& Doblin 2014. Active water transport in unicellular algae: where, why, and how. J. Exp. Bot. 65:6279-92.

Raven, J. A. \& Ralph, P. J. 2015. Enhanced biofuel production using optimality, pathway modification and waste minimization. J. Appl. Phycol. 27:1-31.

Raven, J. A. \& Richardson, K. 1984. Dinophyte flagella: A cost-benefit analysis. New. Phytol. 98:259-76.

Raven, J. A. \& Waite, A. M. 2004. The evolution of silicification in diatoms: Inescapable sinking and sinking as escape? New Phytol. 162:45-61.

Richardson, T. L. \& Cullen, J. J. 1995. Changes in buoyancy and chemical composition during growth of a coastal marine diatom: Ecological and biogeochemical consequences. Mar. Ecol. Prog. Ser. 128:77-90.

Shikata, T., Matsunaga, S., Nishide, H., Sakamoto, S., Onistuka, G. \& Yamaguchi, M. 2015. Diurnal vertical migration rhythms and their photoresponse in four phytoflagellates causing harmful algal blooms. Limnol. Oceanogr. 60:1251-64.

Sikes, C. S. \& Wilbur, K. M. 1982. Functions of coccolith formation. Limnol. Oceanogr. 27:1826.

Sleigh, M. A. \& Blake, J. R. 1977. Methods of cliary propulsion and their size limitations. In: Pedley, T. J. [Ed.] Scale effects in animal evlution. Academic Press, London, pp. 243-58.

Smetacek, V. S. 1985. Role of sinking in diatom life-history cycles - Ecological, evolutionary and geological significance. Mar. Biol. 84:239-51.

Solari, C. A., Kessler, J. O. \& Michod, R. E. 2006. A Hydrodynamics Approach to the Evolution of Multicellularity: Flagellar Motility and Germ-Soma Differentiation in Volvocalean Green Algae. Am. Nat. 167:537-54.

Spielmeyer, A., Gebser, B. \& Pohnert, G. 2011. Investigations of the Uptake of Dimethylsulfoniopropionate by Phytoplankton. Chembiochem 12:2276-79.

Stefels, J. 2000. Physiological aspects of the production and conversion of DMSP in marine algae and higher plants. J. Sea Res. 43:183-97.

Stefels, J., Dacey, J. W. H. \& Elzenga, J. T. M. 2009. In vivo DMSP-biosynthesis measurements using stable-isotope incorporation and proton-transfer-reaction mass spectrometry (PTRMS). Limnol. Oceanogr.: Methods 7:595-611.

Sullivan, C. W. 1976. Diatom mineralization of silicic acid 1. Si(OH) $)_{4}$ transport characteristics in Navicula pelliculosa. J. Phycol. 12:390-96.

Sunda, W., Kieber, D., Kiene, R. \& Huntsman, S. 2002. An antioxidant function for DMSP and DMS in marine algae. Nature 418:317-20.

This article is protected by copyright. All rights reserved. 
Sverdrup, H. U., Johnson, M. W. \& Fleming, R. H. 1942. The oceans: their physics, chemistry and general biology. Prentice Hall, Englewood Cliffs, New Jersey,

Swift, D. M. \& Wheeler, A. P. 1992. Evidence of an organic matrix from diatom biosilica. $J$. Phycol. 28:202-09.

Thornton, D. C. O. 2002. Diatom aggregation in the sea: mechanisms and ecological implications. Eur. J. Phycol. 37:149-61.

Van Donk, E., Ianora, A. \& Vos, M. 2011. Induced defences in marine and freshwater phytoplankton: a review. Hydrobiologia 668:3-19.

Van Donk, E., Lurling, M., Hessen, D. O. \& Lokhorst, G. M. 1997. Altered cell wall morphology in nutrient-deficient phytoplankton and its impact on grazers. Limnol. Oceanogr. 42:357-64.

Vila-Costa, M., Simó, R., Harada, H., Gasol, J. M., Slezak, D. \& Kiene, R. P. 2006. Dimethylsulfoniopropionate uptake by marine phytoplankton. Science 314:652-54.

Villareal, T. A. \& Carpenter, E. J. 1994. Chemical composition and photosynthetic characteristics of Ethmodiscus rex (Bacillariophyceae): Evidence for vertical migration. J. Phycol. 30:1-8.

Villareal, T. A. \& Lipshultz, F. 1995. Internal nitrate concentrations in single cells of large phytoplankton from the Sargasso Sea. J. Phycol. 31:689-96.

Villareal, T. A., Pilskaln, C. H., Montoya, J. P. \& Dennett, M. 2014. Upward nitrate transport by phytoplankton in oceanic waters balancing nutrient budgets in oligotrophic seas. PeerJ:2:e302; DOI 10.7717/peerj.302.

Waite, A. M., Fisher, A., Thompson, P. A. \& Harrison, P. J. 1997. Sinking rate versus cell volume relationships illuminate sinking rate control mechanisms in marine diatoms. Mar. Ecol. Prog. Ser. 157:97-108.

Walsby, A. E. 1994. Gas vesicles. Microbiol. Rev. 58:94-144.

Woods, S. \& Villareal, T. A. 2008. Intracellular ion concentrations and cell sap density in positively buoyant oceanic phytoplankton. Nova Hedwigia:131-45.

Young, J. R. \& Westbroek, P. 1991. Genotypic variation in the coccolithophorid species Emiliania huxleyi. Mar. Micropaleontol. 18:5-23.

\section{Figure legends}

Figure 1: Effect of a $65 \%$ increase in calcite mass per cell on the modeled sinking rate $\left(\mathrm{m} \mathrm{day}^{-1}\right)$ of nitrate-limited E. huxleyi cells as a function of different proportions of cell carbon incorporated in carbohydrate (from 60 to $10 \%$ of cell carbon) and lipid (from 25.25 to $75.25 \%$ of cell carbon).

This article is protected by copyright. All rights reserved. 
Figure 2: (A) Percentage increase in sinking rate (for E. huxleyi and T. pseudonana) or decrease in rising rate (for E. rex) achieved by different ballast strategies (Cell wall formation, polysaccharide storage, and organic solutes replacement by de novo synthesized DMSP) as well as (B) the energy cost of each strategy (as photons absorbed per cell per unit ballast) in three algae species growing in conditions of low $\mathrm{N}$ availability. Error bars in panel A represent the range of modeled values computed using different proportions of cell carbon allocated to carbohydrate and lipid. Error bars in panel B represent the range of photon energy cost per cell per unit ballast taking into account assumptions in carbohydrate and lipid composition per cell as well as other assumptions in the energy cost calculation ( $\mathrm{N}$ source, carbohydrate cell quota, and uncertainty in cell wall composition). The absorbed photon cost per unit ballast is equal to the absorbed photon cost per cell (Table 1) divided by the percentage increase in sinking rate (or decrease in rising rate for E. rex) (Panel A) and multiplied by a constant $\left(10^{14}\right)$. The relative increase in cell wall, carbohydrate or DMSP synthesis in N-limited or N-depleted algae compared to algae growing in optimal conditions is as shown in Table 3.

Figure 3: Effect of a 4.5-fold increase in Si mineralization (low silica: $0.37 \mathrm{~mol} \mathrm{Si} \cdot \mathrm{L}^{-1}$; high silica: $\left.1.75 \mathrm{~mol} \mathrm{Si} \cdot \mathrm{L}^{-1}\right)$ on the modeled sinking rate $\left(\mathrm{m} \mathrm{day}^{-1}\right)$ of nitrate-limited Thalassiosira pseudonana CCMP 1005 cells as a function of different proportions of cell carbon incorporated in carbohydrate (from 60 to $20 \%$ of cell carbon) and lipid (from 5 to $45 \%$ of cell carbon).

This article is protected by copyright. All rights reserved. 
Table 1: Intracellular concentration of inorganic ions $\left(\mathrm{Na}, \mathrm{K}^{+}, \mathrm{Cl}^{-}, \mathrm{SO}_{4}{ }^{2-}, \mathrm{NO}_{3}{ }^{-}\right.$) and organic solutes (TMG, trimethylglycine ; DMSP,

dimethylsulfoniopropionate; $\mathrm{TMA}^{+}$, trimethylammonium) as well as the cellular osmolarity used for modeling the sinking or rising rates of the three species considered in this study.

\begin{tabular}{|c|c|c|c|c|c|c|c|c|c|}
\hline & $\mathrm{Na}^{+}$ & $\mathrm{K}^{+}$ & $\mathrm{Cl}^{-}$ & $\mathrm{SO}_{4}{ }^{2-}$ & $\mathrm{NO}_{3}^{-}$ & TMG & DMSP & $\mathrm{TMA}^{+}$ & Osmolarity \\
\hline & $\mathrm{mM}$ & $\mathrm{mM}$ & $\mathrm{mM}$ & $\mathrm{mM}$ & $\mathrm{mM}$ & $\mathrm{mM}$ & $\mathrm{mM}$ & $\mathrm{mM}$ & $\operatorname{mosmol} \mathrm{L}^{-1}$ \\
\hline E. huxleyi ${ }^{\text {a }}$ & 250 & 110 & $507-523$ & & & $0.5-0$ & $59-110.8$ & $372-21.7$ & 1215.6 \\
\hline T. pseudonana ${ }^{\mathrm{b}}$ & 4.88 & 390 & $507-523$ & & & $0.2-2$ & $0.9-25.9$ & $403-419$ & 1195.0 \\
\hline E. rex ${ }^{\mathrm{c}}$ & 290 & 3.51 & $435-445-$ & 6.2 & 1 & 0 & $0-14.0$ & $370-380$ & 1013.0 \\
\hline
\end{tabular}

${ }^{a}$ The $\mathrm{K}^{+}$concentration was measured in the E. huxleyi strain ASM-1 by Ho et al. (2003). The concentrations of $\mathrm{Na}^{+}, \mathrm{Cl}^{-}$, and $\mathrm{TMA}^{+}$were assumed to achieve a cell osmolarity $20 \%$ higher than that of seawater (partly based on the work of Sikes and Wilbur 1982). DMSP concentrations of 59 and $110.8 \mathrm{mM}$ (as well as TMG concentrations of 0.5 and $0 \mathrm{mM}$ ) were measured in $\mathrm{N}$ replete and N-limited cells, respectively (Keller et al. 1999).

${ }^{\mathrm{b}}$ Intracellular concentrations of inorganic ions are based on a Cl:K:Na ratio $\approx 107: 80: 1$, which is representative of several planktonic diatoms (Boyd and Gradmann 2002). DMSP concentrations of 0.9 and $25.9 \mathrm{mM}$ (as well as the TMG concentrations of 2 and $0.2 \mathrm{mM}$ ) were measured in $\mathrm{N}$ replete and $\mathrm{N}$-limited cells respectively (Keller et al. 1999). $\mathrm{TMA}^{+}$concentrations were assumed to achieve a cell osmolarity $18 \%$ higher than seawater (Guillard 1962).

${ }^{\mathrm{c}}$ Intracellular concentrations of inorganic ions were measured by Beklemishev et al. (1961), Guillard (1962) and Villareal and Lipshultz (1995). The concentrations of DMSP, and $\mathrm{TMA}^{+}$were assumed to achieve a cell osmolarity iso-osmotic to seawater (Raven and Doblin 2014).

This article is protected by copyright. All rights reserved. 
Table 2: Organic carbon cell quotas, cell radius (equivalent spherical cell radius) and cellular quotas of various structural materials (protein, carbohydrate, lipid, calcite, and silica) used for modeling the sinking or rising rates of the three species considered in this study.

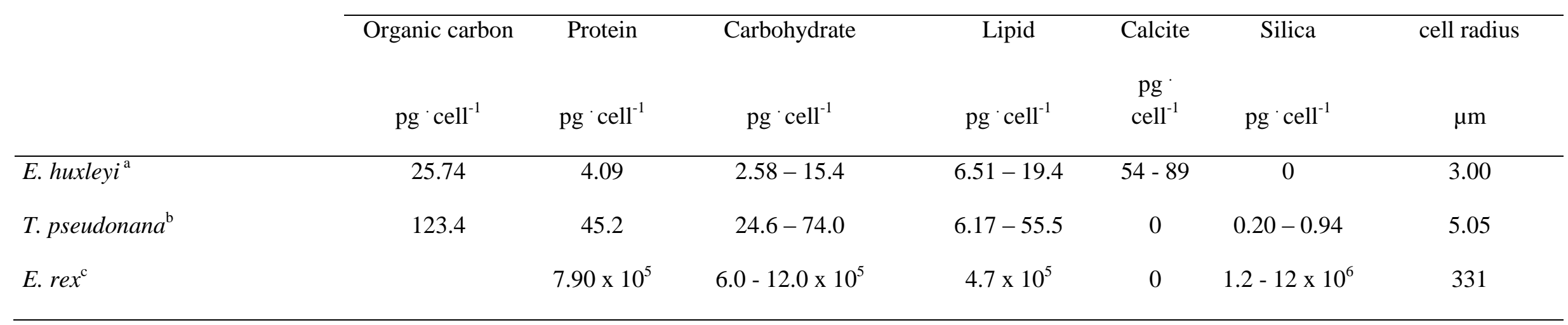

\footnotetext{
${ }^{a}$ Organic carbon and calcite cell quotas were from Paasche et al. (1998). A cell radius representative of those of several E. huxleyi strains was chosen. Protein cell quota was measured by Keller et al. (1999) and different proportions of the remaining cell organic carbon were allocated to carbohydrate and lipid.
}

${ }^{\mathrm{b}}$ Organic carbon cell quota, protein cell quota, and cell radius were measured by Keller et al. (1999). Silica content was modeled according to Conley et al. (1989) and a range of carbohydrate and lipid quotas were assumed.

${ }^{c}$ Equivalent spherical cell radius from Villareal and Carpenter (1994). The cellular quotas of carbohydrate, protein, and lipid were computed with the empirical relationships of Hitchcock (1982). Silica was modeled from the cell volume according to the equations of Conley et al. (1989).

This article is protected by copyright. All rights reserved. 
Table 3: Energy cost (expressed as absorbed photons or nitrogen) of different cell mechanisms increasing the sinking rate of three algae species (E. huxleyi, T. pseudonana and E. rex) in conditions of low N availability. A range of absorbed photon costs per cell values is computed depending on assumptions in the calculations (i.e., $\mathrm{NO}_{3}{ }^{-}$or $\mathrm{NH}_{4}{ }^{+}$as the $\mathrm{N}$ source, different proportions of cell carbon allocated to carbohydrate as well as uncertainties in the composition of the cell wall; see Appendix S1 sections 5, 6, 7, and 8 for further details about the energy cost calculations of de novo DMSP synthesis, siliceous cell wall formation, coccolith formation, and polysaccharide storage, respectively). The relative increase of each cell component in N-limited or N-depleted algae compared to optimally growing algae is denoted in parenthesis in the first column.

\begin{tabular}{|c|c|c|c|c|c|}
\hline & & \multicolumn{4}{|c|}{ Energy cost of each ballast strategy } \\
\hline & & \multicolumn{2}{|c|}{ Absorbed photon cost } & \multicolumn{2}{|c|}{ Nitrogen cost } \\
\hline & & mol photons per cell & $\%$ of cell photon cost & mol $\mathrm{N}$ per cell & $\%$ of cell $\mathrm{N}$ \\
\hline Coccolith (1.55x) & E. huxleyi & $1.5-1.9 \times 10^{-12}$ & $2.98-3.64$ & Low & Low \\
\hline Polysaccharides (1.56x) & E. huxleyi & $1.2-4.9 \times 10^{-12}$ & $2.36-9.48$ & Low & Low \\
\hline DMSP $(1.5 x)$ & E. huxleyi & $2.2-2.4 \times 10^{-13}$ & $0.43-0.47$ & $-2.48 \times 10^{-15}$ & -2.1 \\
\hline Si cell wall $(4.7 x)$ & T. pseudonana & $7.6-20 \times 10^{-12}$ & $3.1-8.2$ & $0.11-0.18 \times 10^{-12}$ & 24 to 40 \\
\hline Polysaccharide (1.56x) & T. pseudonana & $8.8-29 \times 10^{-12}$ & $3.6-12$ & Low & Low \\
\hline DMSP (27.8x) & T. pseudonana & $0.29-0.48 \times 10^{-12}$ & $0.12-0.20$ & $-9.72 \times 10^{-15}$ & -1.9 \\
\hline Si cell wall $(4 \mathrm{x})$ & E. rex & $2.5-5.7 \times 10^{-8}$ & $1.1-2.4$ & \multicolumn{2}{|c|}{ Potentially high } \\
\hline Polysaccharide (1.5x) & E. rex & $1.0 \times 10^{-7}$ & 4.3 & Low & Low \\
\hline Synthesis of $14 \mathrm{mM}$ DMSP & E. rex & $5.7-8.3 \times 10^{-8}$ & $2.4-3.5$ & $-1.52 \times 10^{-9}$ & -22 \\
\hline
\end{tabular}

This article is protected by copyright. All rights reserved. 
Figure 1

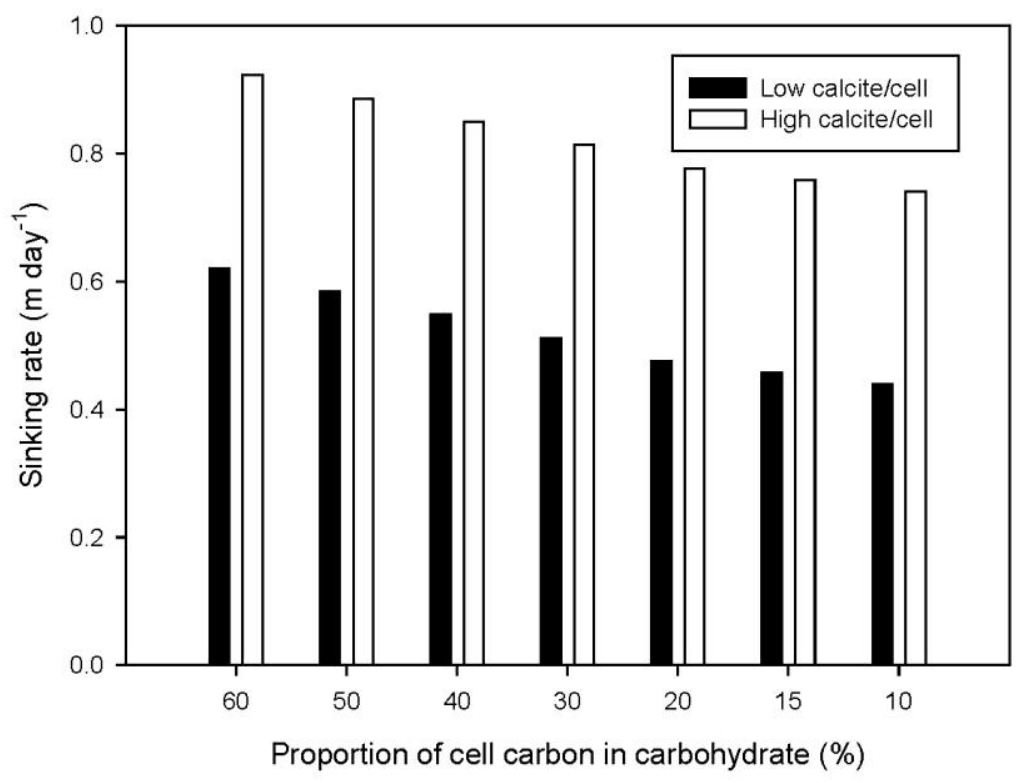

This article is protected by copyright. All rights reserved. 
Figure 2
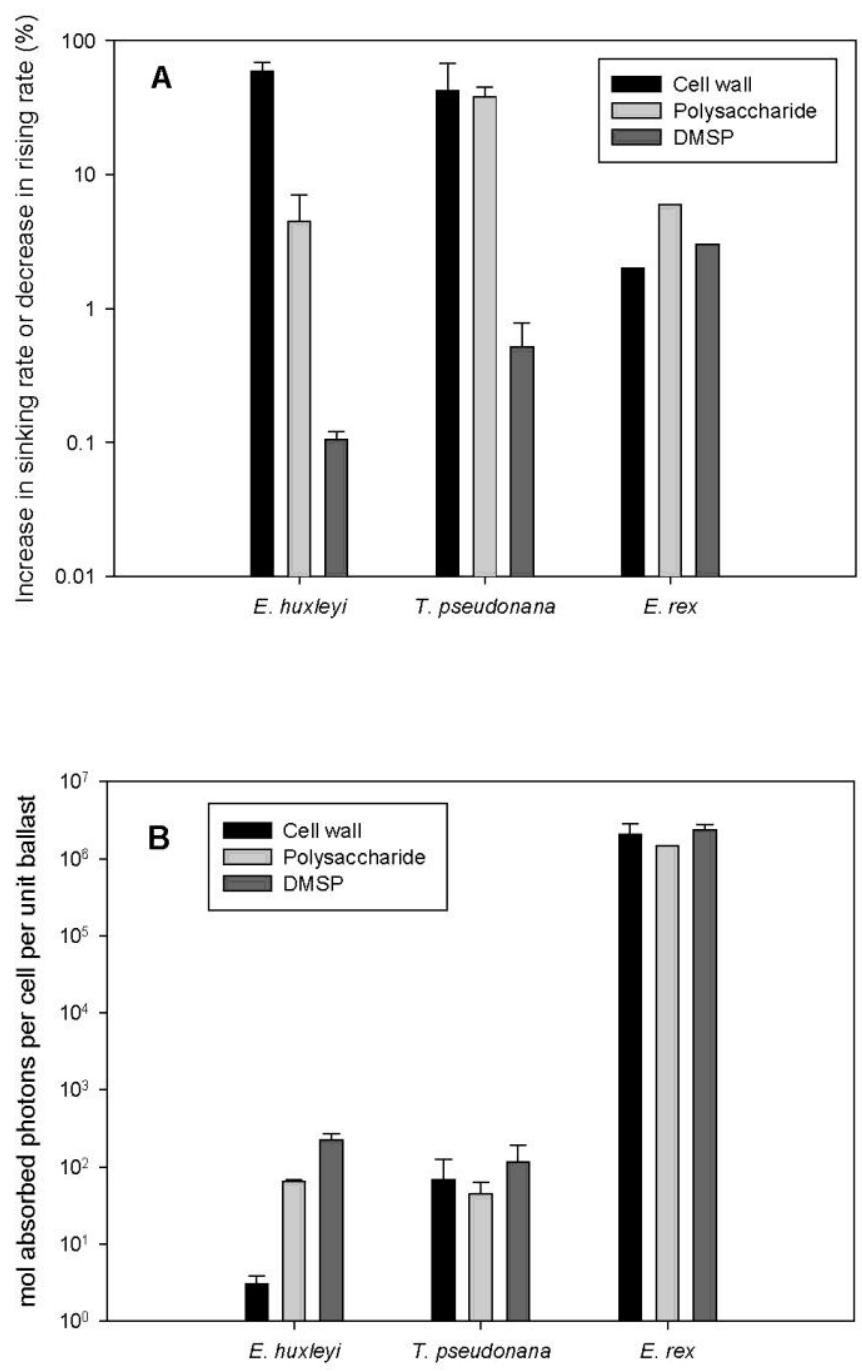

This article is protected by copyright. All rights reserved. 
Figure 3

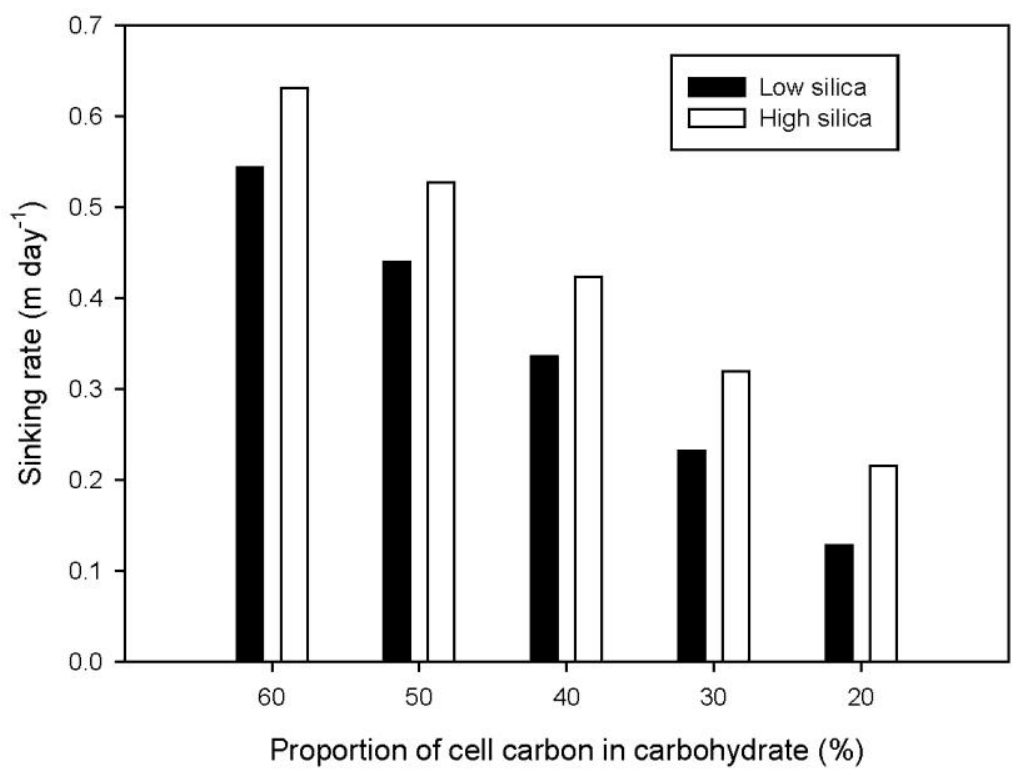

This article is protected by copyright. All rights reserved. 